\title{
Biogeography of neutral genes and recent evolutionary history of pines in the Mediterranean Basin
}

\author{
Bruno Fady
}

Received: 6 November 2011 / Accepted: 8 May 2012 /Published online: 15 June 2012

(C) INRA / Springer-Verlag France 2012

\begin{abstract}
- Context Mediterranean pines share many common lifehistory traits. They are found at almost all altitudinal levels around the Mediterranean Basin, from sea level to highelevation mountains, and from hot and dry to wet and cold bioclimates. Their distribution ranges from widespread to regional and narrow, and from dense extensive populations to small populations of scattered individuals. They have been extensively used by human civilizations for millennia. - Aims I show which are the main phylogenetic, ecological, and climatic factors explaining the patterns of within and among-population genetic diversity in Mediterranean pines. - Methods I use a narrative synthesis approach and multiple examples from the literature on pine species from the Mediterranean Basin and California.

- Results While Mediterranean pines have the highest levels of differentiation worldwide, their genetic diversity increases from west to east and is significantly reduced in low-elevation species. Factors such as ancestral adaptation to wildfire, reduction of effective population size during the Last Glacial Maximum, long distance dispersal during the Holocene, and more recent adaptation to patchy environmental conditions could explain these patterns.

- Conclusion Because of contrasted ecological, demographic, historical, and geographical processes, and despite their common biological attributes, pines of the Mediterranean Basin display complex biogeographic patterns at neutral gene level that can help retrace their evolutionary history.
\end{abstract}

Handling Editor: Eric Rigolot

B. Fady $(\bowtie)$

INRA, UR629, Ecologie des Forêts Méditerranéennes (URFM),

Domaine St Paul, site Agroparc,

84914 Avignon, France

e-mail: Bruno.Fady@avignon.inra.fr
Although individual species often represent unique case studies that make generalizations risky, locating habitats of significantly high and low genetic diversity is key for detecting and understanding the major factors affecting gene diversity and may prove useful for profiling areas of high conservation value in the Mediterranean.

Keywords Genetics · Pinus · Mediterranean · Climate · Diversity · Differentiation · Biogeography $\cdot$ Conservation · Phylogeny $\cdot$ Ecology $\cdot$ Adaptation

\section{Introduction}

With 109 recognized species native to most of the biomes of the Northern Hemisphere, pines (genus Pinus) are the largest and most widespread of all conifers in the world (Farjon 2008). Along with Central America and Eastern Asia, the Mediterranean biome (see Quézel and Médail 2003 for a definition) has a large share of this diversity. Although they occupy only $1.8 \%$ of the world's terrestrial habitats (Fady and Médail 2004), Northern Hemisphere Mediterranean regions are rich with at least 28 pine species $(25 \%$ of all pine species), 11 in the Mediterranean Basin and 17 in California. In the remaining regions of the world under Mediterranean climate (the South African Cape Province, South and South-Western Australia, and parts of Central Chile, in total $0.2 \%$ of the world's terrestrial habitats), pines constitute a rare-enough example of a highly successful invasive tree genus (Richardson and Rejmánek 2011).

Due to their high economic and ecological importance, pines have been extensively studied. Studies focusing on Mediterranean pines are comparatively underrepresented. A Web of Knowledge search using keywords "pinus and mediterran* yielded less than 9,000 records to compare with 
more than 300,000 references published after 1946 when using "Pinus" as keyword! Those studies trying to understand how the great diversity of Mediterranean pines is geographically structured in an evolutionary context are even fewer (less than 600 hits using keywords "pinus and mediterran* and (evolution* or biogeog*)"!). The focus of this review will be on pines endemic to the Mediterranean Basin, comparing them with their Californian counterparts when possible, with the aim to highlight how their neutral gene diversity follows unusual biogeographic patterns, a legacy of their recent evolutionary history driven by climatic and land-use changes, building on older phylogenetic imprints.

\section{Pines in the Mediterranean basin: highlights on species richness, ecology, and history}

The ecological diversity of the comparatively small group of pines found in the Mediterranean Basin is no less than what it is in much of the Northern Hemisphere. From the infraMediterranean altitudinal belts where the first scattered populations of Pinus halepensis can be found in North Africa, to the oro-Mediterranean belt where the last Pinus nigra populations form scattered and bushy stands in the Balkans and Turkey, pines are ubiquitous in the Mediterranean Basin (Table 1). Up to 11 native species are described under Mediterranean-type climate in the Old World (Price et al. 1998). From most drought resistant to most cold tolerant: Pinus pinea L., P. halepensis Mill., Pinus brutia Ten., P. canariensis C. Smith, Pinus pinaster Aiton, Pinus heldreichii Christ, Pinus sylvestris L., P. nigra Arnold, Pinus peuce Gris., and the two mountain pines Pinus uncinata Mill. ex Mirbel and Pinus mugo Turra. P. halepensis and P. brutia are often considered as the two members of a species complex (Fady et al. 2003) and so are P. uncinata and P. mugo (Heuertz et al. 2010).

Distribution areas of Mediterranean pines are large and continuous (e.g., P. halepensis/brutia; Fady et al. 2003), large but fragmented (e.g., P. nigra; Isajev et al. 2005), or small and isolated (e.g., P. heldreichii; Vendramin et al. 2008b). Within species, independently of distribution area size and structure, populations tend to be large and to form dense stands extending from the thermo- to the mountainMediterranean altitudinal belts (Quézel and Médail 2003; Fady and Médail 2004), except at altitudinal extremes and in ecologically and geographically marginal situations where population size may be considerably smaller (such as rearedge populations, Hampe and Petit 2005).

Although they form a group of species of nonhomogeneous phylogenetic origin (Klaus 1989, and see below for details), Mediterranean pines share a set of common life history traits. Seeds and pollen (as in most pine species) are wind-dispersed, with the notable exception of $P$. pinea whose seeds are gravity and animal dispersed (as they are in other pine species with large seeds). Fire-adaptive traits such as thick bark and self-pruning (fire-tolerator pine syndrome; Keeley 2012) and early onset of flowering and serotinous cones (fire-embracer pine syndrome; Keeley 2012) are also shared in Mediterranean pines, although restricted to lowelevation pines (Tapias et al. 2004).

Pines of the Mediterranean Basin have played a significant ecological and economic role for humans for millennia (Barbero et al. 1998). Ancient Egyptians, Phoenicians, Greeks, Romans and many other civilizations harvested and managed pines extensively in various ways and for various purposes. Today, the economic importance of Mediterranean pines continues for timber and pulp production, fuel, food, watershed management, ecological restoration, and amenities.

Table 1 Main woody vegetation types in the Mediterranean Basin, from low to high elevations ( $m$ in the mean temperature of the coldest month and $T$ is the mean annual temperature, in degree Celcius)

\begin{tabular}{|c|c|c|c|c|}
\hline Altitudinal belt & Temperature variant & $m\left({ }^{\circ} \mathrm{C}\right)$ & $T\left({ }^{\circ} \mathrm{C}\right)$ & Dominant woody species \\
\hline Infra-Mediterranean & Very hot & $>+7{ }^{\circ} \mathrm{C}$ & $>+17{ }^{\circ} \mathrm{C}$ & Argania spinosa, Acacia gummifera, (Pinus halepensis) \\
\hline Thermo-Mediterranean & Hot & +3 to $+7{ }^{\circ} \mathrm{C}$ & $>+17{ }^{\circ} \mathrm{C}$ & $\begin{array}{l}\text { Olea sp., Ceratonia siliqua, P. halepensis, } \\
\text { Pinus brutia, Pinus pinaster, Pinus pinea } \\
\text { (sclerophyllous Quercus, Tetraclinis articulata) }\end{array}$ \\
\hline Meso-Mediterranean & Temperate & 0 to $+3{ }^{\circ} \mathrm{C}$ & +13 to $+17{ }^{\circ} \mathrm{C}$ & $\begin{array}{l}\text { Sclerophyllous Quercus, } P \text {. halepensis, P. brutia, } \\
\text { P. pinaster }\end{array}$ \\
\hline Supra-Mediterranean & Cool & -3 to $0{ }^{\circ} \mathrm{C}$ & +8 to $+13{ }^{\circ} \mathrm{C}$ & $\begin{array}{l}\text { Deciduous Quercus, Pinus nigra } \\
\quad \text { (Ostrya carpinifolia, Carpinus orientalis, P. brutia) }\end{array}$ \\
\hline Mountain- Mediterranean & Cold & -7 to $-3{ }^{\circ} \mathrm{C}$ & +4 to $+8{ }^{\circ} \mathrm{C}$ & $\begin{array}{l}\text { P. nigra, Pinus sylvestris, Cedrus sp., Abies sp., } \\
\text { Fagus sp., Juniperus sp. (P. heldreichii) }\end{array}$ \\
\hline Oro-Mediterranean & Very cold & $<-7^{\circ} \mathrm{C}$ & $<+4{ }^{\circ} \mathrm{C}$ & Juniperus sp., prostrate spiny xerophytes $(P$. nigra) \\
\hline
\end{tabular}

Species names in parentheses are rare at a given altitudinal belt. With $m$ mean minimum temperatures of the coldest month, $T$ mean annual temperature. This large-scale ecological gradient has many different local scale variants depending on rainfall, soil type and land-use. From Fady and Médail (2004) and Quézel and Médail (2003) 
Overall, Mediterranean pines share common life history traits, common types of distribution areas and stand structures as well as a common history of interaction with human civilizations. They occupy an ecological region, the Mediterranean, known for its sharp climatic, landscape, and climatic contrasts. Genetic differences found between groups of ecologically similar species and across the spectrum of habitats they occupy may thus indicate differences in their evolutionary history under strong environmental drivers.

\section{Mediterranean pines have unusual population genetic features}

\subsection{The genetic diversity of Mediterranean pines in a biogeographic context}

During the four last decades of the twentieth century, a wealth of studies used isozymes, a class of enzymes with simple and Mendelian inheritance to estimate neutral genetic diversity among and within populations (Hamrick et al. 1992) and thus infer evidence that demography was a strong driver of diversity. Although studies including Mediterranean pines lagged behind those of other tree species in the Temperate and Tropical worlds, by the early years of the twenty-first century, enough isozyme data was available in Mediterranean pines for synthesis and analysis (Fady 2005). Mediterranean pine species display much more genetic differentiation and less genetic diversity within population than other conifers in the Mediterranean (and elsewhere in the world). And this diversity is not randomly arranged in space at a large biogeographical scale. More recent molecular studies based on microsatellites have confirmed this trend of neutral genetic diversity (Fady and Conord 2010; Soto et al. 2010).

With the rise of sophisticated high-throughput molecular biology techniques, studies on allelic variation at loci involved in the expression of phenotypic traits have become available for Mediterranean pines (e.g., Eveno et al. 2008). Allelic variation at genes coding for adaptive (fitness related) traits are governed both by natural selection and, indirectly, by demographic factors. Although there are currently not enough such studies available for robust meta-analysis, patterns of genetic variation at these loci is also not randomly arranged (e.g., Grivet et al. 2011), which can help understand the role of natural selection on genetic diversity of Mediterranean pines at large biogeographical scales.

\subsection{Mediterranean pines have highly genetically} differentiated populations

Mediterranean pines are among the most genetically differentiated tree species worldwide, with an average differentiation (Gst) of 0.13 at isozyme loci, when Gst in Mediterranean woody species is 0.11 (Fady 2005) and Gst for conifers worldwide is 0.07 (Hamrick et al. 1992). Conversely, Mediterranean pines are as genetically diverse within population (heterozygosity, $\mathrm{He}=0.155$ at isozyme loci) as conifers worldwide ( $\mathrm{He}=0.151$; Hamrick et al. 1992), and significantly less than Mediterranean conifers $(\mathrm{He}=0.182$; Fady 2005). $P$. pinaster, for example, is a typically high differentiation and moderate diversity pine. Endemic to the western Mediterranean Basin (Alia and Martin 2003), its gene diversity measured from five cpSSR loci is $H=0.825$ whereas eight different genetic groups from three different lineages form a clear range-wide geographic pattern with a Gst $=0.09$ (Bucci et al. 2007).

\subsection{Xerothermic pines have less genetic diversity} than mesothermic and mountain pines in the Mediterranean

The second of these outstanding features is that Mediterranean xerothermic pine species (those found at low elevation where the mean minimum temperature of the coldest month, $m$ is $>0{ }^{\circ} \mathrm{C}$, Table 1) have less genetic diversity than mesothermic and mountain pines. This is also true for Californian pines (Fady and Conord 2010). Genetic diversity of Californian and Mediterranean xerothermic pines is $\mathrm{He}=0.055$ (isozyme loci) whereas it is $\mathrm{He}=0.185$ for meso- and mountainMediterranean pines (Fady 2005), a higher diversity than that found for conifers elsewhere in the world $(\mathrm{He}=0.185 \mathrm{com}$ pared to 0.151, see above). Soto et al. (2010) demonstrated this trend to be true in the Iberian Peninsula using the same set of cpSSR markers for all six Iberian pines. Cold-resistant mountain pines (P. uncinata, P. nigra, and P. sylvestris) were found substantially more diverse than low-elevation xerothermic pines ( $P$. halepensis and $P$. pinea), with $P$. pinaster displaying intermediate values.

P. pinea, the Italian stone pine, is a typical, albeit extreme, example of low diversity xerothermic Mediterranean pine. With a large range covering the entire Mediterranean Basin (Fady et al. 2004), most of its populations have no diversity at isozyme loci (Fallour et al. 1997) and are fixed for a single common cpSSR haplotype. In total, only four haplotypes are found, three of them located in the Eastern Mediterranean. Such cases of depauperate genetic diversity are extremely rare for largely distributed species, particularly trees (Vendramin et al. 2008a). In comparison, the mountain pine species complex (P. uncinata/mugo) display much more genetic diversity within population $(H=0.96$ for three cpSSR loci) and little differentiation (Gst=0.070; Heuertz et al. 2010).

3.4 The genetic diversity of Mediterranean pines increases from west to east

The $P$. halepensis/brutia species complex is typical of an increasing west to east trend in genetic diversity found in 
many conifers broadly distributed in the Mediterranean Basin (Fig. 1a). Its heterozygosity (isozyme loci) increases significantly from almost 0 in Spain to close to 0.1 in Greece. Heterozygosity then reaches values well above 0.1 in Turkey where only P. brutia is present (Fady 2005). This longitudinal pattern is also expressed, albeit more weakly, in P. nigra and P. sylvestris (Fady and Conord 2010) and the lowest diversity $P$. uncinata and $P$. mugo populations are found in Spain and the Pyrenees (Heuertz et al. 2010). As for $P$. pinea, its few genetic variants are mostly in the Eastern Mediterranean (Vendramin et al. 2008a). Such a geographic structure is unusual in the Northern Hemisphere phylogeographic context where within population genetic diversity is commonly described to follow latitudinal patterns (Hewitt 2000).

\subsection{Evolutionary and ecological factors explaining} the original genetic diversity of Mediterranean pines

Several hypotheses, not mutually exclusive, can be proposed to explain the original genetic features of pines of the Mediterranean Basin: increasing from west to east, lower in xerothermic than other pines and more spatially structured than expected. They result from the interplay of gene flow and selection (Young et al. 1996; Le Corre and Kremer 1998; Savolainen et al. 2007) which, in the Mediterranean Basin, have taken an original course at various spatial and temporal scales.

\subsection{Climatic and tectonic processes affecting species} diversity and genetic diversity in parallel

Genetic diversity and species diversity have been shown to vary in parallel (Vellend and Geber 2005) because they are driven by similar demographic (migration and drift) and ecological (selection) processes. Just like genetic diversity, species diversity is unusually high in the Mediterranean Basin. Nearly $20 \%$ of the world's plants have their habitat there (Médail and Quézel 1999) while its total land surface is less than $2 \%$ of the world's land mass. This and a high level of endemism make the Mediterranean Basin a "biodiversity hot spot" (Myers et al. 2000). Pre-Pleistocene tectonic factors are commonly recognized to explain species diversity in the Mediterranean where plant taxa both from Laurasia and the remains of Gondwana are intermixed and Asian lineages are frequent (Petit et al. 2005). Later Pleistocene glacial cycles further increased species diversity, although probably not in conifers that were already well differentiated at the end of the Tertiary (Eckert and Hall 2006). Similarly, Quaternary glacial refugia acted as hotspots of genetic diversity (Petit et al. 2003). Populations of Mediterranean and European taxa remained isolated from each other for several tens of thousands of years repeatedly throughout the Pleistocene, limiting possibilities for extensive gene flow and generating strongly genetically divergent populations (Petit et al. 2005; Rodriguez-Sanchez et al. 2010). Tectonic and climatic processes leading to geographic heterogeneity and fragmentation can certainly explain congruent genetic and species differentiation spatial patterns. Médail and Diadema (2009) have identified a mosaic-type pattern of phylogeographic hotspots (refugial zones with high genetic uniqueness) congruent overall with the presence of regional hotspots of species diversity and endemism, many localized in the three Mediterranean peninsulas. If such historical processes can explain the high level of differentiation found in Mediterranean pines, other factors, though, remain to be found to explain their within-population altitudinal and longitudinal spatial patterns (Fig. 1a and b).

3.7 The phylogenetic imprint and the emergence of fire-adaptive traits

Using a strict consensus tree built on DNA sequence variation at two plastidic loci, rbcl and matK, Gernandt et al. (2005) demonstrated that pines of the Mediterranean Basin have a common Old World phylogenetic origin dated to 128 million years (MY) ago. Low- and mid-elevation Mediterranean pines (and P. heldreichii) belong to subgenus Pinus, section Pinus, subsection Pinaster while mountain Mediterranean pines belong to the same subgenus and section but to subsection Pinus. P. peuce, on the other end, belongs to an entirely different subgenus (Strobus) making it more similar to Pinus cembra L. (the Swiss stone pine) than to Mediterranean pines. Mountain Mediterranean pines also differ from lower-elevation pines by their age. Mountain Mediterranean pines form a 20-MY-old Oligocene group whereas lower-elevation Mediterranean pines make up a 96-MY-old Cretaceous group (Eckert and Hall 2006). Common phylogenetic origin can force congruent levels of genetic diversity to appear in congeneric species. For example, congeneric taxa are known to express similar levels of genetic diversity irrespective of their distribution status (widespread vs endemic; Gitzendanner and Soltis 2000). A likely phylogenetic imprint in pines of subgenus Pinus is adaptation to wildfire (Keeley 2012). Fire-adaptive phenotypic and functional traits (e.g., early cone onset and serotinous cones under high intensity fires and thick bark and self-pruning under low intensity fires) are widespread in subgeneus Pinus (Pausas et al. 2004; Fernandes and Rigolot 2007) and constitute evolved strategies (Schwilk and Ackerly 2001). Their emergence is dated to after $126 \mathrm{MY}$, during the fire-prone lower Cretaceous (He et al. 2012), at the time of emergence of pines of the Mediterranean Basin. A likely outcome of repeated wildfires is also the reduction of effective population size and loss of genetic diversity within population. Adaptation to fire can thus explain the low genetic diversity of low-elevation pines in 
(a)

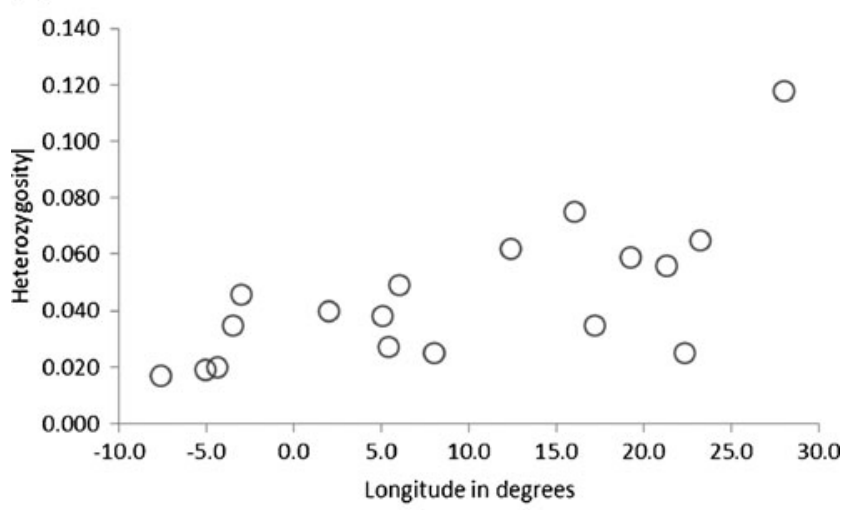

(b)

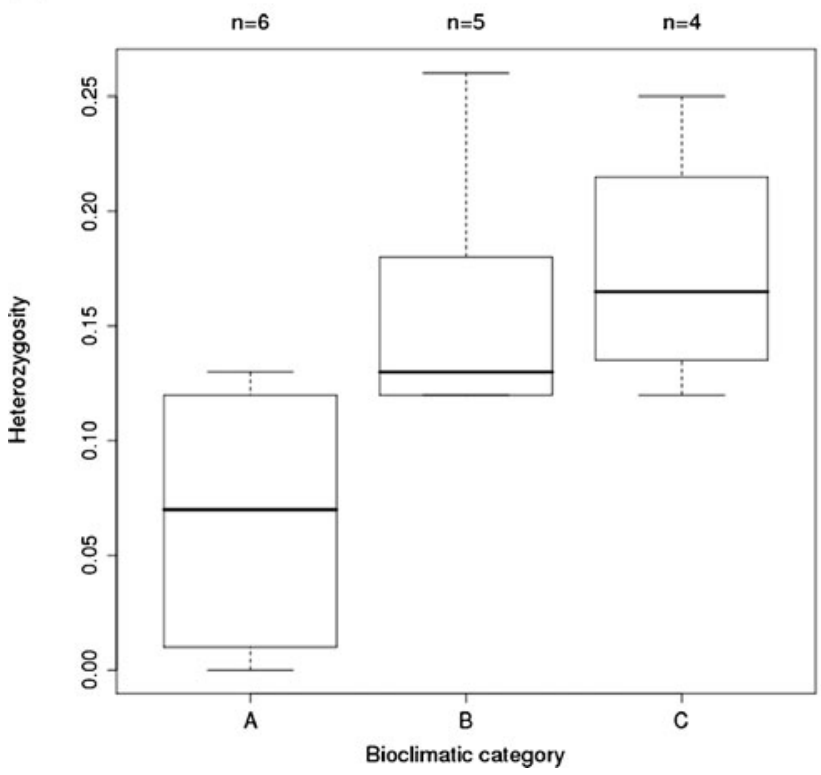

Fig. 1 Trends in the within-population genetic diversity of Mediterranean pines. a $P$. halepensis, a case study of west-to-east increasing diversity (correlation between longitudinal position and heterozygosity is 0.44 with a $p$ value of 0.002 , data from Fady (2005)). The easternmost dot corresponds to the mean heterozygosity of $P$. brutia in Turkey. b Increase in diversity from low elevation xerothermic pines $(A)$ to mid-elevation mesothermic pines $(B)$ and high elevation mountain pines $(C) p$ value of 0.03 for the genetic differentiation among the three zones, data from California and Mediterranean basin pines in Fady and Conord (2010))

the entire subgenus Pinus (from the Mediterranean Basin pines of section Pinus, subsection Pinaster to the Californian pines of section Trifoliae, subsections Australes and Ponderosae). However, in these clades, many species have retained comparatively large levels of neutral genetic diversity (e.g., Pinus canariensis; Gómez et al. 2003) as well as of adaptive variation in wildfire adaptive traits (Santos-del-Blanco et al. 2010). The genetic differences between low and higherelevation pines may thus also be found in processes related to more recent events.
3.8 The genetic consequences of the Last Glacial Maximum and the Holocene: drift, recolonization and/or adaptation

Recolonization via founder effects and demographic bottlenecks under adverse local environmental conditions can both lead to low genetic diversity within populations and high differentiation (Young et al. 1996; Le Corre and Kremer 1998). Despite their ability for long-distance dispersal, habitat fragmentation was also found to be a powerful driver of within population genetic loss in woody plants (Vranckx et al. 2012). Such demographic processes are likely to have happened in the Mediterranean. The existence of Eastern Mediterranean refugia and their role in the Holocene recolonization of Europe has been widely acknowledged for major forest species (Magri et al. 2006; Liepelt et al. 2009). Perhaps more significant for the Mediterranean and its populations trapped in southern glacial refugia, is the fact that climate during the Last Glacial Maximum (LGM) was much harsher (drier and colder) in Western Europe and the Mediterranean and becoming gradually more favorable going east (van Andel 2002). Both recolonization from refugia in the Eastern Mediterranean into the Western Mediterranean and local survival of populations under an LGM climate of increasing severity from east to west, would lead to a decreasing trend of genetic diversity from east to west in the Mediterranean.

$P$. halepensis provides an interesting case study where demographic bottlenecks seem as likely to have imprinted its current genetic diversity as long distance recolonization. This pine has the typical low genetic diversity of lowelevation Mediterranean pines, markedly increasing from west to east. The spatial structure of gene ancestry at eight nuclear genes involved in drought response suggests that Aleppo pine recolonized its almost peri-Mediterranean distribution area during the Holocene from eastern Mediterranean refugia and underwent selection along the way in its new habitats (Grivet et al. 2009). This hypothesis is also presented by Gomez et al. (2005) using the distribution of chloroplast microsatellite variability in the Iberian Peninsula as evidence. As an alternative hypothesis to this longdistance dispersal recolonization scenario, Fady and Conord (2010), looking at genetic diversity at isozyme loci, suggested that Aleppo pine suffered strong demographic bottlenecks in the western part of its distribution area at the LGM, whereas it did not in its eastern part where LGM climate was more favorable. This hypothesis does not involve longdistance dispersal and is based on the probable existence of local populations throughout the Mediterranean Basin at LGM, as modeled by Benito-Garzón et al. (2007) for Spain.

Local survival under harsh environmental conditions during the LGM and more broadly throughout the Quaternary glacial cycles was proposed for $P$. pinea as well (Vendramin 
et al. 2008a). More generally, the hypothesis of local survival under adverse environmental conditions provides a straightforward explanation of the lower diversity and effective population size of Western Mediterranean populations and of all thermophilous low-elevation pines, including low-elevation Californian pines (Fig. 1b) (Fady and Conord 2010).

Additional factors may play an important role in generating low diversity within and high differentiation among low-elevation pine populations. The low-elevation pines $P$. halepensis and $P$. pinaster are pioneer species, with comparatively shorter life cycles and juvenile phases than average in trees, which can be expected to significantly increase differentiation and decrease genetic diversity (Austerlitz et al. 2000). However, many higher-elevation pines which do not display significant differentiation and low diversity can also be considered as pioneer species. Yet also, repeated wildfires and other anthropogenic habitat modifications over the last few millennia may have increased demographic bottleneck effects in low-elevation pines, particularly so in California (Pausas et al. 2006).

Finally, adaptation to local and regional environmental conditions may have influenced genetic diversity. Differences among populations within species for fitness-related traits can significantly modify the expected distribution of species (Benito Garzon et al. 2011). It is thus likely that the necessity to adapt locally will have modified the structure of Mediterranean pines. Eveno et al. (2008) have shown that allelic patterns at candidate genes clearly diverge from neutral expectations in P. pinaster. Grivet et al. (2011) then showed that allele frequencies at some of these candidate genes correlate significantly with different temperature indices across the range of both $P$. pinaster and $P$. halepensis. Sensitivity to temperature (Climent et al. 2009) or to (its proxy) elevation (Kurt et al. 2012) rather than to water availability (Chambel et al. 2007; Lamy et al. 2011) seems to be the dominant driver of Mediterranean pine adaptive diversity range-wide. Local adaptation is widespread in natural populations (Savolainen et al. 2007). Yet, despite intense selection, diversity within population remains significant. At the edge of species ranges, where local adaptation may break down (Savolainen et al. 2007), genetic diversity can be lost due to natural selection and demographic bottlenecks and thus explain such patterns as those found for Mediterranean pines. However, adaptation is more likely to result in mosaic-type patterns of diversity rangewide because of the highly diverse ecological conditions where species can survive, as shown for $P$. pinaster by Gonzalez Martinez et al. (2002) and for predator-prey relationships in $P$. halepensis by Mezquida and Benkham (2005). Convergent selection results in populations of different evolutionary lineages to display similar levels adaptive diversity (Gonzalez Martinez et al. 2004).

\section{Conclusion}

Pines belong to a genus of distant evolutionary history and effects imprinted in their genomes are possibly quite old. The high differentiation found among populations can be due to the more recent genetic imprint of the complex topography and geography of the Mediterranean. Congruent levels of neutral genetic diversity in the Mediterranean Basin and in California also point to the likely role of past climate on the demography of resident populations during glacial periods. Resident populations remaining in suitable but reduced and fragmented habitats under unfavorable climatic conditions are likely to have suffered genetic bottlenecks (Vranckx et al. 2012), thus contributing significantly lower genetic diversity to locally recolonized populations. It has been shown theoretically that both long distance recolonization and the presence of multiple cryptic refugia can produce the same spatial patterns of distribution range-wide (Roques et al. 2010). This perspective brings new light to the role of past climate on genetic diversity, more frequently acknowledged for its imprint via Holocene recolonization dynamics (Hewitt 2000) than directly on the effective size of resident populations, as suggested here. With climate change predicted to increase its impact, low elevation pines are likely to play an increasingly important ecological role in the future. Although they seem to retain some (sometimes very limited) level of adaptive diversity (Chambel et al. 2007), their low neutral diversity, indicative of strong genetic bottlenecks, could be of concern for conservation and future adaptation.

According to Hewitt (2004): "The present genetic constitution of populations and species carries attenuated signals of [...] past dynamics". However, trying to infer ecological and demographic processes and the role of environmental factors from spatial genetic patterns is certainly not straightforward. There is much to be gained by synthesizing results from many studies at large spatial scales when factors act concurrently on a process. However, such efforts may also blur factors affecting single species differently, or in opposite ways. In general, species-rich Mediterranean regions of the world where enough past climate data are available can provide further experimental data to decipher the role of climate on genetic diversity, directly via demographic bottlenecks and break down of local adaptation, or indirectly via long distance dispersal and recolonization. Within the genus Pinus, recent and increasingly developing advances in genomics make testing for signature of selection possible across distribution areas for key processes (see Grivet et al. 2011 for the role of selection for drought resistance in $P$. halepensis and $P$. pinaster), providing opportunities to further disentangle the roles of demography and selection on genetic diversity. A better understanding of the role of past environmental factors on pine genomes may 
be useful for a more comprehensive evaluation of their future in a changing world!

Acknowledgments This research was made possible by financial support from the European Network of Excellence EVOLTREE, from the Eranet Biodiversa LINKTREE project and from the European Union Capacities Program AGORA project. I thank F. Lefèvre and three anonymous reviewers for helpful comments on the manuscript.

\section{References}

Alía R., Martín S (2003) EUFORGEN Technical Guidelines for genetic conservation and use for Maritime pine (Pinus pinaster). International Plant Genetic Resources Institute, Rome, Italy

Austerlitz F, Mariette S, Machon N, Gouyon P-H, Godelle B (2000) Effects of colonization processes on genetic diversity: differences between annual plants and tree species. Genetics 154:1309-1321

Barbéro M, Loisel R, Quézel P, Richardson DM, Romane F (1998) Pines of the Mediterranean Basin. In: Richardson DM (ed) Ecology and biogeography of Pinus. Cambridge Univ. Press, Cambridge

Benito-Garzón M, de Dios RS, Ollero HS (2007) Predictive modelling of tree species distributions on the Iberian Peninsula during the Last Glacial Maximum and Mid-Holocene. Ecography 30:120-134

Benito-Garzón M, Alia R, Robson TR, Zavala MA (2011) Intraspecific variability and plasticity influence potential tree species. Glob Ecol Biogeogr 20:766-778

Bucci G, Gonzalez-Martinez SC, Le Provost G, Plomion C, Ribeiro MM, Sebastiani F, Alia R, Vendramin GG (2007) Range-wide phylogeography and gene zones in Pinus pinaster Ait. revealed by chloroplast microsatellite markers. Mol Ecol 16:2137-2153

Chambel MR, Climent J, Alía R (2007) Divergence among species and populations of Mediterranean pines in biomass allocation of seedlings grown under two watering regimes. Ann For Sci 64:87-97

Climent J, Costa e Silva F, Chambel MR, Pardos M, Almeida MH (2009) Freezing injury in primary and secondary needles of Mediterranean pine species of contrasting ecological niches. Annals of Forest Science, 66, article 407

Eckert AJ, Hall BD (2006) Phylogeny, historical biogeography, and patterns of diversification for Pinus (Pinaceae): phylogenetic tests of fossil-based hypotheses. Mol Phylogenet Evol 40:166-182

Eveno E, Collada C, Guevara MA, Léger V, Soto A, Díaz L, Léger P et al (2008) Contrasting patterns of selection at Pinus pinaster Ait. drought stress candidate genes as revealed by genetic differentiation analyses. Mol Biol Evol 25:417-437

Fady B (2005) Is there really more biodiversity in Mediterranean forest ecosystems? Taxon 54:905-910

Fady B, Conord C (2010) Macroecological patterns of species and genetic diversity in vascular plants of the Mediterranean Basin. Divers Distrib 16:53-64

Fady B, Médail F (2004) Mediterranean forest ecosystems. In: Burley J, Evans J, Youngquist JA (eds) Encyclopedia of forest science. Elsevier, London, pp 1403-1414

Fady B, Semerci H, Vendramin GG (2003) Technical guidelines for genetic conservation and use for Aleppo pine (Pinus halepensis) and Brutia pine (Pinus brutia). EUFORGEN. International Plant Genetic Resources Institute, Rome, 6p

Fady B, Fineschi S, Vendramin GG (2004) EUFORGEN technical guidelines for genetic conservation and use for Italian stone pine (Pinus pinea). International Plant Genetic Resources Institute, Rome

Fallour D, Fady B, Lefèvre F (1997) Study on isozyme variation in Pinus pinea L.: evidence of low polymorphism. Silvae Genetica 46:201-207

Farjon A (2008) A natural history of conifers. Timber Press, Portland
Fernandes P, Rigolot E (2007) The fire ecology and management of maritime pine (Pinus pinaster Ait.). For Ecol Manag 241:1-13

Gernandt DS, Lopez GG, Garcia SO, Liston A (2005) Phylogeny and classification of Pinus. Taxon 54:29-42

Gitzendanner MA, Soltis PS (2000) Patterns of genetic variation in rare and widespread plant congeners. Am J Bot 87:783-792, 2000

Gómez A, González-Martínez SC, Collada C, Climent J, Gil L (2003) Complex population genetic structure in the endemic Canary island pine revealed using chloroplast microsatellite markers. Theor Appl Genet 107:1123-1131

Gómez A, Vendramin GG, González-Martínez SC, Alía R (2005) Genetic diversity and differentiation of two Mediterranean pines (Pinus halepensis Mill. and Pinus pinaster Ait.) along a latitudinal cline using chloroplast microsatellite markers. Divers Distrib $11: 257-263$

González Martínez SC, Alía R, Gil L (2002) Population genetic structure in a Mediterranean pine (Pinus pinaster Ait.): a comparison of allozyme markers and quantitative traits. Heredity 89:199-206

González-Martínez SC, Mariette S, Ribeiro MM, Burban C, Raffin A, Chambel MR, Ribeiro CA et al (2004) Genetic resources in maritime pine (Pinus pinaster Aiton): molecular and quantitative measures of genetic variation and differentiation among maternal lineages. For Ecol Manag 197:103-115

Grivet D, Sebastiani F, Gonzalez-Martinez SC, Vendramin GG (2009) Patterns of polymorphism resulting from long-range colonization in the Mediterranean conifer Aleppo pine. New Phytol 184:1016-1028

Grivet D, Sebastiani F, Alia R, Bataillon T, Torre S, Zabal-Aguirre M, Vendramin GG, Gonzalez-Martinez SC (2011) Molecular footprints of local adaptation in two mediterranean conifers. Mol Biol Evol 28:101-116

Hampe A, Petit RJ (2005) Conserving biodiversity under climate change?: the rear edge matters. Ecology Letters 8(5):461-467

Hamrick JL, Godt MJW, Sherman-Broyles SL (1992) Factors influencing levels of genetic diversity in woody plant species. New For 6:95-124

He T, Pausas JG, Belcher CM, Schwilk DW, Lamont BB (2012) Fireadapted traits of Pinus arose in the fiery Cretaceous. New Phytol 194:751-759

Heuertz M, Teufel J, González-Martínez SC, Soto A, Fady B, Alía R, Vendramin GG (2010) Geography determines genetic relationships between species of mountain pine (Pinus mugo complex) in Western Europe. J Biogeogr 37:541-556

Hewitt G (2000) The genetic legacy of the Quaternary ice ages. Nature 405:907-913

Hewitt G (2004) Genetic consequences of climatic oscillations in the Quaternary. Phil Trans Roy Soc Lond B 359:183-195

Isajev V, Fady B, Semerci H, Andonowski V (2005) Technical guidelines for genetic conservation and use of European black pine (Pinus nigra). EUFORGEN. International Plant Genetic Resources Institute, Rome, $6 \mathrm{p}$

Keeley JE (2012) Ecology and evolution of pine life histories. Ann For Sci 69. doi:10.1007/s13595-012-0201-8

Klaus W (1989) Mediterranean pines and their history. Plant Systematics and Evolution 162:133-163

Kurt Y, González-Martínez SC, Alia R, Isik K (2012) Genetic differentiation in Pinus brutia Ten using molecular markers and quantitative traits: the role of altitude. Ann For Sci 69:34345-34351

Lamy JB, Bouffier L, Burlett R, Plomion C, Cochard H et al (2011) Uniform selection as a primary force reducing population genetic differentiation of cavitation resistance across a species range. PLoS One 6:e23476

Le Corre V, Kremer A (1998) Cumulative effects of founding events during colonisation on genetic diversity and differentiation in an island and stepping-stone model. J Evol Biol 11:495-512

Liepelt S, Cheddadi R, de Beaulieu JL, Fady B, Gömöry D, Hussendörfer E, Konnert M, Litt T, Longauer R, Terhürne-Berson R, Ziegenhagen 
B (2009) Postglacial range expansion and its genetic imprints in Abies alba (Mill.) - a synthesis from paleobotanic and genetic data. Rev Palaeobot Palynology 153:139-149

Magri D, Vendramin GG, Comps B, Dupanloup I, Geburek T, Gomory D, Latalowa M, Litt T, Paule L, Roure JM, Tantau I, van der Knaap WO, Petit RJ, de Beaulieu JL (2006) A new scenario for the Quaternary history of European beech populations: palaeobotanical evidence and genetic consequences. New Phytol 171:199-221

Médail F, Diadema K (2009) Glacial refugia influence plant diversity patterns in the Mediterranean Basin. J Biogeogr 36:1333-1345

Médail F, Quézel P (1999) Biodiversity hotspots in the Mediterranean basin: setting global conservation priorities. Conserv Biol 13: $1510-1513$

Mezquida ET, Benkman CW (2005) The geographic selection mosaic for squirrels, crossbills and Aleppo pine. J Evol Biol 18:348-357

Myers N, Mittermeier RA, Mittermeier CG, da Fonseca GAB, Kent J (2000) Biodiversity hotspots for conservation priorities. Nature $403: 853-858$

Pausas J, Bradstock R, Keith D, Keeley J (2004) Plant functional traits in relation to fire in crown-fire ecosystems. Ecology 85: $1085-1100$

Pausas JG, Keeley JE, Verdu M (2006) Inferring differential evolutionary processes of plant persistence traits in Northern Hemisphere Mediterranean fire-prone ecosystems. J Ecol 94:31-39

Petit RJ, Aguinagalde I, de Beaulieu JL, Bittkau C, Brewer S, Cheddadi R, Ennos R, Fineschi S, Grivet D, Lascoux M, Mohanty A, Muller-Starck GM, Demesure-Musch B, Palme A, Martin JP, Rendell S, Vendramin GG (2003) Glacial refugia: hotspots but not melting pots of genetic diversity. Science 300:1563-1565

Petit RJ, Hampe A, Cheddadi R (2005) Climate changes and tree phylogeography in the Mediterranean. Taxon 54:877-885

Price RA, Liston A, Strauss SH (1998) Phylogeny and systematics of Pinus. In: Richardson DM (ed) Ecology and biogeography of Pinus. Cambridge Univ Press, Cambridge

Quézel P, Médail F (2003) Ecologie et biogéographie des forêts du bassin méditerranéen. Elsevier, Paris

Richardson DM, Rejmánek M (2011) Trees and shrubs as invasive alien species-a global review. Divers Distrib 17:788-809
Rodriguez-Sanchez F, Hampe A, Jordano P, Arroyo J (2010) Past tree range dynamics in the Iberian Peninsula inferred through phylogeography and palaeodistribution modelling: a review. Rev Palaeobot Palynol 162:507-521

Roques L, Hamel F, Fayard J, Fady B, Klein EK (2010) Recolonisation by diffusion can generate increasing rates of spread. Theor Popul Biol 77:205-212

Santos-del-Blanco L, Notivol E, Zas R, Chambel MR, Majada J, Climent J (2010) Variation of early reproductive allocation in multi-site genetic trials of Maritime pine and Aleppo pine. For Syst 19:381-392

Savolainen O, Pyhäjärvi T, Knürr T (2007) Gene flow and local adaptation in trees. Ann Rev Ecol Evol Syst 38:595-619

Schwilk DW, Ackerly DD (2001) Flammability and serotiny as strategies: correlated evolution in pines. Oikos 94:326-336

Soto A, Robledo-Arnuncio JJ, Gonzalez-Martinez SC, Smouse PE, Alia R (2010) Climatic niche and neutral genetic diversity of the six Iberian pine species: a retrospective and prospective view. Mol Ecol 19:1396-1409

Tapias R, Climent J, Pardos JA, Gil L (2004) Life histories of Mediterranean pines. Plant Ecol 171:53-68

Van Andel TH (2002) The climate and landscape of middle part of Weichselian glaciation in Europe: the stage 3 project. Quat Res $57: 2-8$

Vellend M, Geber MA (2005) Connections between species diversity and genetic diversity. Ecol Lett 8:767-781

Vendramin GG, Fady B, González-Martínez SC, Hu FS, Scotti I, Sebastiani F, Soto A, Petit RJ (2008a) Genetically depauperate but widespread: the case of an emblematic Mediterranean pine. Evolution 62:680-688

Vendramin GG, Fineschi S, Fady B (2008b) EUFORGEN Technical Guidelines for genetic conservation and use of Bosnian pine (Pinus heldreichii). Bioversity International, Rome, p 6

Vranckx G, Jacquemyn H, Muys B, Honnay O (2012) Meta-analysis of susceptibility of woody plants to loss of genetic diversity through habitat fragmentation. Conserv Bio 26:228-237

Young A, Boyle T, Brown T (1996) The population genetic consequences of habitat fragmentation for plants. Trends Ecol Evol 11:413-418 